\title{
FIRST MORMON HANDCART TRIP ACROSS IOWA
}

Following is from a copy of a camp journal kept by a secretary of the first Mormon handcart company which passed from Iowa City, then the terminus. of the railroad, across Iowa in 1856. It was sent to the Curator of the Historical Department on October 2, 1926, by Andrew Jensen of Salt Lake City, Utah, who was an efficient worker in the office of the historian of the Mormon church. Permission was offered us by him to publish it. In accordance with $\mathrm{Mr}$. Jensen's suggestion we have endeavored to shed further light upon the location of the trail, and have put such explanations into footnotes.

Mr. Jensen was a gnest of the Curator of this Department in 1925 for some two weeks. With the manuscript of this journal, and with certified copies of the notes of the United States land surveyors who originally set the township, range and section lines (of both the earlier Mormon Trail from Nauvoo to Council Bluffs, and) of this Handcart Trail, in their hands these two friends actually retrod the footsteps, paused at the camp sites and observed the hills and the streams forming impediments the men, women and children a-foot overcame or succumbed to.-F. R. Harlan, August 27, 1936.

Following is an account of the crossing of the Plains by Captain Edmund Ellsworth's handeart company, as copied and culled from the official journal kept by Andrew Galloway, secretary of the company:

Monday, June 9, 1856. At 5 P.M. the handcarts were in motion, proceeding Zionward (from the camp ground west of Iowa City). The Saints were in excellent spirits. 'The camp traveled about 4 miles and pitched their tents for the night.

T'uesday, June 10. The emigrants remained in camp all day, owing to the fact that three yoke of oxen had strayed away from the herd. While some of the brethren went out in search of the animals, the Saints in camp engaged in various duties.

Wednesday, June 11. Early in the morning, the strayed cattle were brought to camp, and about 8 A.M. the company started forward. $A$ fter traveling 5 miles, encampment was made for the night. The carts of Brothers Robinson and Jones broke down.

Thursday, June 12. The journey was resumed at 6 A.M., and the company traveled 12 miles, over a very dusty road. Tents were pitched about 2 p.x., the Saints were in good spirits. 
Friday, June 13. The journcy was continued about 8 A.s., over good roads, and all went well. During the day a number of strangers visited with the Saints, who traveled that day 7 miles.

Saturday, June 14. The company resumed the journey at 6 A.s. in good spirits, and traveled 7 miles, over good roads. Tents were pitched at 9 A.s. 'Toward evening, James Ferguson arrived from the general camp. About 6 P.s. William Lee, the 12-year-old son of John l.ce, died of consumption.

Sunday, June 15. The Saints remained in camp and held two meetings. The morning meeting which was commenced at 10:30 A.s. was addressed by Elder Joseph. France, and the afternoon meeting, commencing at 1:30 p.x., by Edward Frost. A great number of strangers attended the meetings and they all paid good attention. At 9 oclock in the morning, Lora Praeter, daughter of Richard Praeter, died of whooping cough; she was 3 years old. At $7: 30$ p.s. the sacrament was administered to the two companies. It was a time of rejoicing for all. Eilder Ferguson addressed the Saints. About 9 P.M. the remains of the two children who bad died were interred on the banks of Little Bear Creek. ${ }^{1}$ [In Iowa County, 35 miles from Iowa City.]

Monday, June 16. At 6:30 A.x. the company resumed the journey in good spirits. After traveling 13 miles the company rested from 11:30 A.x. until 4 p.x. on Big Bear Creek. After traveling 2 miles further in the afternoon, encampment was formed for the night. About 9 1.s. the camp was visited by a rainstorm.

Tuesday, Juno 1\%. The bugle was blown at 4 A.M. for all hands to turn out. The company moved at $6: 45$ A.x., traveled 10 miles, then rested 2 hours, and at 2:20 P.xr. tents were pitched for the night at a place where there was no wood, but plenty of water. About 3 P.x. Job Welling, son of Job Welling Sr., age 1 year and 7 months, died of canker or inflammation of the bowels.

Wodnesday, June 18. At 4 A.M. the bugle sounded for all to rise and at $5: 20$ the company resumed the journey, traveled 10 miles without accident, and pitched tents at $8: 35$ A.M., in order to give the sisters an opportunity of washing their clothes. During the day, the remains of Job Welling's little son were interred at a point 3 feet from the north-east corner of Mr. Watson's farm, in Section 25, 'Township 80, Range 17 West.'

Thursday, Juno 19. The camp rolled out at 7:45 A.3r. and traveled 15 miles without accident. Encampment for the night was made about noon at a place where wood and water was plentiful. Several of the Saints were rebaptized for their health by Elder John Oakley.

Friday, June 20 . 'The camp moved at 6:45 A.M., traveled 16 milcs over a very hilly and rather rough country, making the day's journey very hard. In the morning, John Lloyd, wife and family "backed out."

1This was at Little Bear Creek, about four miles soutliwest of Marengo, Iowa County. It flows into Big Bear Creek from the south.

2In the southeastern part of Rock Creek Township, Jasper County, and about three miles southwest from Grinnell. 
He was very much given to drinking whisky along the road. The company passed through the town of Newton in the morning about 9 o'clock. A halt was made from 10 to 12 o'clock, and tents were pitched for the night at 4 P.s. on the banks of a beautiful stream of water, ${ }^{3}$ where there was plenty of wood. Several of the Safnts were baptized for their health by Elder Oakley.

Saturday, June 21. At 6:50 A.M. the camp moved on, traveled 13 miles, rested 30 minutes by the side of a stream, and later an hour on the top of a hill. About 1 p.s. tents were pitched for the night. in a grove where there was plenty of wood and water. At 4:45 p.s. James Bowers died of quick consumption, aged 44 years.

Sunday, June 22. The remains of James Bowers were buried near two other graves, a quarter of a mile east of the main line for Fort Des Moines, in Section 26, Township 79, Range 22.4 The camp was called together for meeting at 4:20 P.sr. Elders Wm. Heaton, Daniel D. McArthur and Edmund Ellsworth preached and gave good instructions.

Monday, June 23. The camp resumed the journey at $7: 25$, traveled 10 miles and pitched tents at 10 A.Mr. The roads were rather rough and dusty part of the way and led through a hilly country. During the day, the company crossed two good sized streams. Encampment was made for the night, 4 miles $^{5}$ from Fort Des Moines, where wood and water was plentiful. In the morning the company passed through a small town ${ }^{6} 7$ miles from the Fort.

Tuesday, June 24. The camp rolled out at 6:30 A.м., traveled 11 miles over a somewhat rough and dusty road. 7 The day was exceedingly warm, and it was rather hard pulling for the handcart boys. Tents were pitched at $1: 30$ P.M. at a place where wood and water was plentiful. About half a mile from the camp, on the left side of the road, an old mobocrat came into camp and tried to make a fuss with Capt. Ellsworth. Sydney Shinn, son of James and Mary Shinn, died in the morning. He was buried 30 yards south of the bridge on the bank of Four Mile Creek, ${ }^{8}$ under an elm tree.

Wednesday, June 25. The camp resumed the journey at 6:25 A.m. and traveled 19 miles. A gentle, refreshing breeze blew nearly all day. The roads were good. 'There was plenty of water at Six Mile Creek and at Nine Mile Creek. Tents were pitched at $1: 45$ on the bank of a river, ${ }^{9}$ where there was plenty of wood.

Thursday, June 26 . The camp moved off this morning at $6: 30$ A.M., traveled 10 miles, forded the river Raccoon, about 1 mile from the camping ground, passed the town of $\mathrm{Ba}-{ }^{10}$ at 12 o'clock noon. 'The

3This was doubtless Soutl Skunk Kiver about 10 miles southwest of Newton. 4Apparently in southeastern part of Beaver Township, Polk County. sLikely camped on Four Mile Creek.

6Doubtless Rising Sun. which they passed through early that day, then camped on Four Mile Creek.

7They must have passed through Fort Des Moines during this day

8 This burial was in the morning of June 24 , before they had left camp on Four Mile Creek.

OLikely the Raccoon River.

10Likely Wiscotta, about one mile south of the present town of Redfield. 
camp again forded the river and camped on the west bank where there was plenty of wood and water. The road was good, with the exception of passing over two or three hills. Emma Sheen (2 years and 8 months old) daughter of Robert and Eliza Sheen, died of whooping cough.

Friday, June 2\%. The body of Emma Sheen was buried in the morning. 12 feet south of a walnut tree, on the west bank of the Raccoon River, opposite the saw mill. At 7 A.sr., the camp rolled out, traveled 10 miles over good roads and camped at 10:30 A.m. in a beautiful valley on the banks of a good sized stream.11 On the west bank of the stream is a beautiful spring of water.

Saturday, June 28. The camp moved at 5:40 A.x. and traveled 16 miles over good roads, except certain parts of it, which led through a hilly country. For a distance of about 13 miles, the water was scarce, but the emigrants were supplied with water at Bear Station.12 Tents were pitched at 1 p.x., and near the camping ground there was plenty of water while wood was rather scarce. During a heavy thunder storm, about 6 P.Mr., one of the tents was blown down, while other tents were rent from top to bottom.

Sunday, June 29. The company remained in camp ${ }^{13}$ all day to rest. The weather was fine. Several strangers visited the camp. About 4:21 p.M. the Saints met together for worship, and the meeting was addressed by Elders Samuel Hargreave, Edmund Ellsworth, Daniel D. McArthur and Spicer W. Crandall.

Monday, June 30. The camp moved out at 6:55 A.M., traveled 16 miles, during the day, and 12 miles without resting. Part of the day, the road led through a hilly country, and there was no water for 12 miles.14 'Tents were pitched at 1:10 P.M. at a place where there was plenty of wood and water. A good spirit prevailed in camp.

Tuesday, July 1. The camp moved out at $7: 19$ A.M., traveled 15 miles over a rather rough road, passed a creek and camped for the night on the bank of a creek; wood was plentiful about half a mile from the camp. About 10:30 p.s. a thunder storm visited the camp, during which one tent was blown down and another one rent.

Wednosday, July 2. The company remained encamped until 3:50 P.x., owing to Brother MeArtlur's company having lost a boy on the way. After starting, the company traveled 10 miles, camped about an hour on the banks of the Nishnabotna River, ${ }^{15}$ a short distance northwest of an Indian town situated on the banks of a river. ${ }^{16}$ 'The camping ground was a most delightful one.

Thursday, July 3. The company resumed the journey at 9:45 A.M. and traveled 14 miles. After traveling 6 miles a halt was made on the

11Likely the South Raccoon River at a point some three miles south of the present city of Guthrie Center.

12L,ater known as Bear Grove, some eight miles southwest of Guthrie Center. 13This camp was evidently about three miles west of Bear Grove.

14.June 30 they must have traversed most of the southern part of Audubon County.

15The main branch of the Nishnabotna River runs south through Shelby and Pottawattamie counties. We suppose they crossed it in Pottawattamie County. 10Likely refers to the East Branch of the Nishnabotna. 
bank of a creek, with but very little water. After traveling 12 miles, the company turned down a road leading to the right, and after traveling 2 miles down that road, an encampment was made by the side of a creek with plenty of water, but only a little wood. About 20 of the camp people lost their way, but found their way to camp about midnight.

Friday, July 4. The company moved out at 7:10 A.s. and traveled 20 miles. During the day, they crossed two creeks. The first ten miles they had plenty of water, but the last ten there was none. The roads were good. At 3:15 P.M. encampment was made by the side of a good creek where there was plenty of wood. This place was 14 miles from Council Bluffs. All the emigrants were in good spirits.

Saturday, July 5 . The company remained in camp all day to rest, wash clothes, etc.

Sunday, July 6 . The company remained in camp. $\Lambda$ meeting was held at 4:20 p.x., which was addressed by Elders Andrew Galloway, John Oakley, Edmund Ellsworth, and Daniel D. McArthur. 'The meeting was attended by quite a number of strangers, some of whom paid good attention, while others, who did not care to hear the doctrines advocated, walked off grumbling.

Monday, July $\%$. The camp rolled out at 7 A.s. and traveled 15 miles through a hilly country; rested 30 minutes on the bank of a good creek. For a distance of about 8 miles, there was little or no water. A few houses were passed about 2 miles from the camping ground, where several old "Mormons" were staying. Tents were pitehed about 5 o'clock P.s.

Tuesday, July 8. The journey was resumed at 7 A.s. and the company traveled 16 miles over a very rough road and up and down hills. One of the handcarts broke down on the way. The company rested on Pigeon Creek about 2 $1 / 2$ hours. Here the company cooked their dinner and got well rested. They then crossed the Missouri River on the steam ferryboat, a short distance below Florence. ${ }^{17}$ They arrived at the camp ground at Florence, about 5 r.M.

Wednesday, July 9 . On this and the few following days, the people of the Edmund Ellsworth company were busily engaged in repairing their handearts, so as to have everything in proper trim for continuing the journey towards the mountains.

Concerning this and similar movements of the Mormons in 1856, files of Iowa newspapers of that date in the Newspaper. Division of the Historical, Memorial and Art Department of Iowa contain statements and comments on the subject, from which we cull those below. The Guthrie Sentinel of Panora of June 21, 1856, presents the following:

17Florence is on the Nebraska side of the Missouri River about six miles north of Omaha. 
Every few days (says the Journal of Commerce) companies of Mormons, varying from two to seven hundred persons, are noticed as landing at some of the Atlantic ports, and proceeding westward. It secms that Iowa City has been selected by the leaders of the church as the place of rendezvous for some 5,000 of their adherents, previous to their finally starting for Utah in July or August. They are principally recruited from England and Scotland. The company which arrived in New York some months ago are temporarily lodged in the railroad buildings in Iowa City, and an encampment of tents has been formed about two miles from the town.

The Daily Muscatine Journal of June 6, 1856, contains this item:

Mormon Emigration.-On Monday afternoon seven car loads of Mormons arrived in this city, enroute for Deseret, Salt Lake. They proceeded to the camp about two miles west of the city where nearly a thousand have been encamped for weeks.-Iowa City Republican, 4th.

In its issue of Junc 20, 1856, the Muscatine Journal gives a clipping from another of its Iowa City exchanges as follows:

Mormons En Route.-Seven car loads of Mormons reached the city today and passed on up to camp-a hard looking set, sweltering in black clothes beneath a sultry sun, and moving on westward like so many mourners for the loss of common sense.-Iowa City Capital RBporter.

\section{A QUICK TRIP TO DES MOINES}

We made the trip to Des Moines, by rail to Eddyville, thence by stage, attended the State Convention all one day, and returned in just two days and ten hours, of course riding two nights in succession. This was quick and would have been pleasant but for the heat and dust. It is a magnificent country between here and Des Moines rendered peculiarly attractive just now by the most magnificent crop of every production the eye ever rested upon.-The Ottumwa Courier, August 7, 1861. (In the Newspaper Division of the Historical, Memorial and Art Department of Iowa.) 
Copyright of Annals of Iowa is the property of State of Iowa, by \& through the State Historical Society of Iowa and its content may not be copied or emailed to multiple sites or posted to a listserv without the copyright holder's express written permission. However, users may print, download, or email articles for individual use. 